The chemical composition and in vitro digestibility evaluation of almond tree (Prunus dulcis D. A. Webb syn. Prunus amygdalus; var. Shokoufeh) leaves versus hulls and green versus dry leaves as feed for ruminants

Mostafa Yousef Elahi, Hassan Kargar, Mohammad Salehi Dindarlou, Ahmed E. Kholif, et al.

\section{Agroforestry Systems}

An International Journal incorporating Agroforestry Forum

ISSN 0167-4366

Agroforest Syst

DOI 10.1007/s10457-016-9964-5

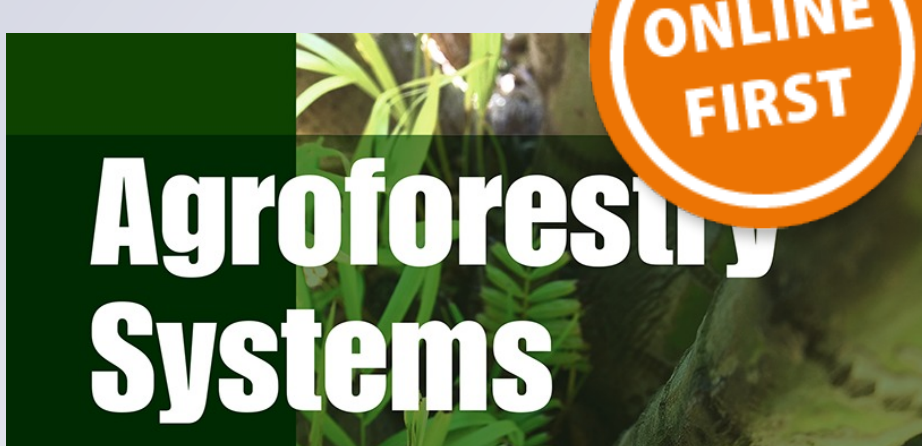

An international journal in cooperation with ICRAF

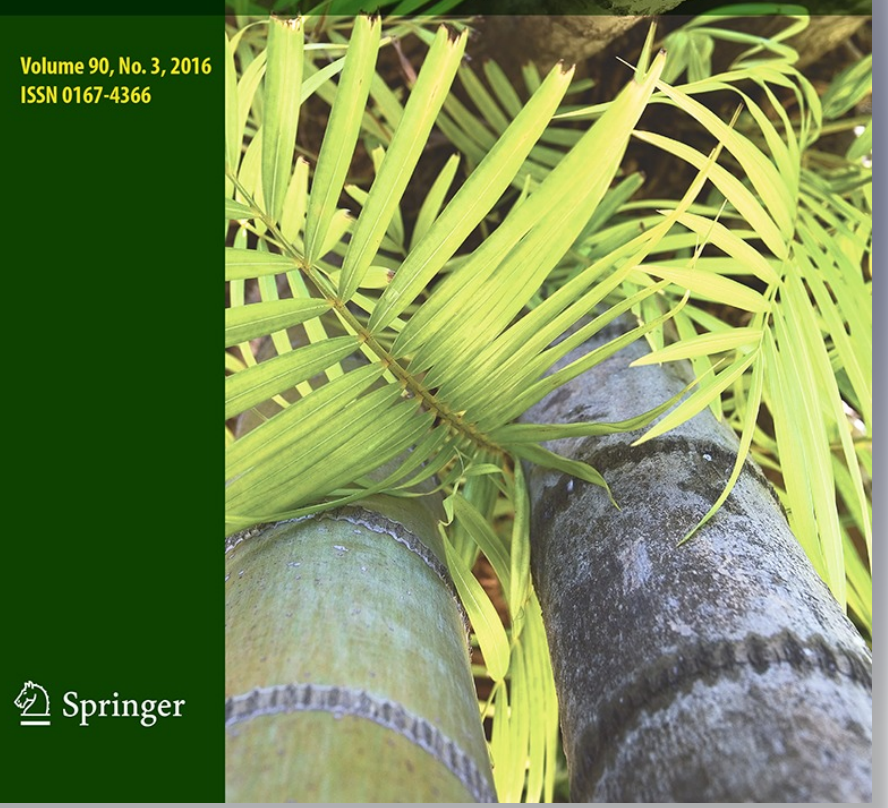


Your article is protected by copyright and all rights are held exclusively by Springer Science +Business Media Dordrecht. This e-offprint is for personal use only and shall not be selfarchived in electronic repositories. If you wish to self-archive your article, please use the accepted manuscript version for posting on your own website. You may further deposit the accepted manuscript version in any repository, provided it is only made publicly available 12 months after official publication or later and provided acknowledgement is given to the original source of publication and a link is inserted to the published article on Springer's website. The link must be accompanied by the following text: "The final publication is available at link.springer.com". 


\title{
The chemical composition and in vitro digestibility evaluation of almond tree (Prunus dulcis D. A. Webb syn. Prunus amygdalus; var. Shokoufeh) leaves versus hulls and green versus dry leaves as feed for ruminants
}

\author{
Mostafa Yousef Elahi - Hassan Kargar - Mohammad Salehi Dindarlou • \\ Ahmed E. Kholif • Mona M. Y. Elghandour • Saul Rojas-Hernández • \\ Nicholas E. Odongo $\cdot$ Abdelfattah Z. M. Salem
}

Received: 12 February 2016/ Accepted: 13 May 2016

(C) Springer Science+Business Media Dordrecht 2016

\begin{abstract}
The current study aimed to evaluate the chemical composition and in vitro digestibility of almond tree (Prunus dulcis D. A. Webb syn. Prunus amygdalus; var. Shokoufeh) leaves versus hulls, and green versus dry leaves as feed for ruminants. The fresh green almond hulls (GAH) and leaves (GAL) were harvested and spread under a shade to dry. Dry almond leaves (DAL) were collected from under the trees where as dry almond hulls (DAH) were collected
\end{abstract}

M. Y. Elahi · H. Kargar · M. S. Dindarlou Department of Animal Science, Faculty of Agriculture, University of Zabol, P.O. Box 98615-538, Zabol, Iran

\author{
A. E. Kholif \\ Dairy Science Department, National Research Centre, 33 \\ Bohouth St. Dokki, Giza, Egypt \\ M. M. Y. Elghandour · A. Z. M. Salem ( $\bigotimes)$ \\ Faculty of Veterinary Medicine and Livestock, \\ Autonomous University of the Mexico State, Toluca, \\ Mexico \\ e-mail: asalem70@yahoo.com \\ S. Rojas-Hernández \\ Unidad Académica de Medicina Veterinaria y Zootecnia, \\ Universidad Autónoma de Guerrero, Chilpancingo, \\ Mexico \\ N. E. Odongo \\ Department of Animal Sciences, School of Agriculture, \\ Pwani University, Kilifi, Kenya
}

4 weeks after harvesting the fresh samples. The chemical composition of substrates was determined using standard approaches and the metabolisable energy (ME), in vitro dry matter (DMD) and in vitro organic matter (OMD) digestibility were measured using the in vitro gas production (GP) technique. The GAL contained $81 \mathrm{~g}$ crude protein $(\mathrm{CP}) \mathrm{kg}^{-1} \mathrm{DM}$ while DAH contained $103 \mathrm{~g} \mathrm{CP} \mathrm{kg}^{-1} \mathrm{DM}$. The CP was higher $(P=0.0003)$ in dry (leaves and hulls) than in green (leaves and hulls) samples. The ash content ranged from 99.2 to $181.5 \mathrm{~g} \mathrm{~kg}^{-1} \mathrm{DM}$ in DAH and DAL, respectively, $(P=0.0041)$. The ether extract content ranged from 27 for DAH to $65 \mathrm{~g} \mathrm{~kg}^{-1}$ for DAL $(P=0.0018)$. The acid detergent fibre and neutral detergent fibre content ranged from 185 to 304 and 444 to $620 \mathrm{~g} \mathrm{~kg}^{-1} \mathrm{DM}(P=0.04)$, for GAL and $\mathrm{DAH}$, respectively. The DAH had the highest $(P=0.0001) \mathrm{GP}_{24}$ and $\mathrm{GP}_{96}$. The DAH had the highest $(P=0.0001)$ potential GP (i.e., $b)$, while the GP rate was highest for GAL and GAH $(P=0.034)$, ME was highest for DAH $(P=0.0001)$, and in vitro OMD was highest for DAH $(P=0.0001)$. The highest DMD $(P=0.0001)$ values were obtained with DAH followed by GAL, DAL and GAH, respectively. It can be concluded that almond hulls and leaves have a good nutritional potential to cover the maintenance nutrient requirements of small ruminants. Almond hulls and leaves can also be used as supplement to low quality mature pasture and/or crop residues. However, more studies are warranted to better characterize these feeds in in vivo animal feeding trials. 
Keywords Almond · Digestibility · In vitro gas production

\section{Introduction}

Almond, (Prunus dulcis D. A. Webb syn. Prunus amygdalus) is a species belonging to the Rosaceae family (Sfahlan et al. 2009). The state of California in the USA is the major producer of almond; however, its production is widely distributed (Wijerante et al. 2006) and there is increasing interest to produce almond and its by-products worldwide. Approximately $2,112,815$ metric ton of almonds with shell is produced globally with Iran contributing about 110,000 metric ton (FAO 2007). Almond is a midsize tree with fruit that can grow up to ten meters tall (Chen et al. 2010). The fruit is made of hulls, shell and kernel. Drying almond hulls results in approximately $\left(\mathrm{kg}^{-1} \mathrm{DM}\right) 250 \mathrm{~g}$ nut, $500 \mathrm{~g}$ hulls and $250 \mathrm{~g}$ shell (Aguilar et al. 1984; Fadel 1999).

The chemical composition and nutritive value of almond hulls has been investigated by many researchers (Alibes et al. 1983; Pinto et al. 1989). The hulls are by-product with low protein, high $\mathrm{N}$-free extract and reasonable energy content. Studies reported that hulls as a feedstuff contained $\left(\mathrm{g} \mathrm{kg}^{-1}\right)$ : $21-80$ of crude protein (CP), 17-30 of ether extract (EE), 280-385 of neutral detergent fibre (NDF), 487-578 of non-fibrous carbohydrate, 596-667 of in vivo dry matter (DM) digestibility (DMD) and 1.9-2.9 Mcal of metabolisable energy (ME) (Alibes et al. 1983; Aguilar et al. 1984; Reed and Brown 1988; Fadel 1999; Alibes et al. 1983; Getachew et al. 2004). In Iran, small ruminants are fed almond tree leaves (green or dry) as a part of diet forage. However, no information is available on the nutritive value of green or dry leaves, as well as dry almond tree hulls. Therefore, the current study aimed to evaluate the chemical composition, in vitro digestibility, and ME of leaves versus hulls, and green versus dry almond tree leaves as feed for ruminants.

\section{Materials and methods}

Sampling zone and collection

This experiment was conducted using almond (Prunus dulcis, syn. Prunus amygdalus; var. Shokoufeh) hulls and leaves from the north-eastern part of Iran (Esferayein, Northern Khorasan). The area is located at an altitude of $1249 \mathrm{~m}$ above sea level. The mean annual rainfall is $300 \mathrm{~mm}$ with moderate air temperature of about $20-25{ }^{\circ} \mathrm{C}$. Almond hulls and leaves were obtained from 10 almond orchards, where at least 10 different trees were sampled, and the hulls and leaves pooled for each garden before analysis, resulting in 10 samples. The trees were aged 15-20 years with heights ranging from 6 to $10 \mathrm{~m}$. The stem diameters were about $30 \mathrm{~cm}$, and the leave lengths ranged from 9 to $12 \mathrm{~cm}$. The leaves were oval and spear to oval in shape with elongated end.

\section{Chemical composition}

The fresh green almond hulls (GAH) and leaves (GAL) were harvested in the autumn. Dry almond leaves (DAL) were collected from beneath the trees i.e., these where dry mature leaves which had fallen off the tree after leaf senescence, dry almond hulls (DAH) were collected 4 weeks after harvesting the green hulls and spread under a shade to dry. The fresh green leaves (GAL) were dried on a bench in the laboratory and ground to pass through $1 \mathrm{~mm}$ sieve for subsequent analyses. Samples were analysed for DM (method ID 934.0) by drying the samples at $105{ }^{\circ} \mathrm{C}$ overnight and the ash content (method ID 942.05) was determined by igniting the samples in a muffle furnace at $550{ }^{\circ} \mathrm{C}$ for 8 h. Nitrogen content (method ID 954.01) was determined using Kjeldahl method (AOAC 1997), where, $\mathrm{CP}$ was calculated as $\mathrm{N} \times 6.25$. Ether extract (method ID 945.16) was determined according to AOAC (1997). Concentrations of NDF and ADF were determined according to Van Soest et al. (1991) using an ANKOM $^{200}$ Fibre Analyser Unit (ANKOM Technology Corp., Macedon, NY, USA) without use of an alpha amylase but with sodium sulphite. Both NDF and ADF are expressed without residual ash. Water soluble carbohydrate (WSC) was measured using the method of MAFF (MAFF 1982). All chemical analyses were carried out in triplicate.

Gas production

The amount of gases produced can be a good indicator of feed fermentability and microbial activity (Elahi et al. 2014; Elghandour et al. 2015a). As described in Cedillo et al. (2014), rumen fluid was obtained from 
three fistulated sheep fed twice daily a diet containing lucerne hay $\left(600 \mathrm{~g} \mathrm{~kg}^{-1}\right)$ and concentrates mixture $\left(400 \mathrm{~g} \mathrm{~kg}^{-1}\right)$ formulated to cover their nutrient requirements (NRC 1985). Sheep had full access to fresh water at all times during the rumen inoculum collection phase. About $200 \mathrm{mg}$ of samples were incubated with $30 \mathrm{~mL}$ of rumen fluid-buffer mixture (ratio of 1:2) in calibrated glass syringes as described by Menke and Steingass (1988). In three runs in 3 different weeks, one hundred and twenty 100-mL calibrated glass syringes (Model Fortuna, Haberle Labortechnik, Germany) with or without substrate (2 foliage types (hulls and leaves) and 2 harvest types (fresh green and dry) $\times 10$ samples (from 10 gardens $) \times 3$ syringes of each triplicate sample plus three syringes as blanks (i.e., rumen fluid only) were used. Syringes were pre-warmed at $39^{\circ} \mathrm{C}$ before the injection of $30 \mathrm{~mL}$ of rumen fluid-buffer mixture into each syringe followed by incubation in a water bath at $39{ }^{\circ} \mathrm{C}$. Reading of gas production (GP) was recorded after 2, 4, 6, 8, 10, 12, 24, 48, 72 and 96 h of incubation. Total GP values were corrected for syringes blank incubated at the same time with other syringes contained samples. The cumulative GP data were fitted to the exponential equation: $P=b\left(1-\mathrm{e}^{-c t}\right)$ of Ørskov and McDonald (1979) where $P$ is the GP at time $t ; b$ is the potential GP (mL $\left.200 \mathrm{mg}^{-1} \mathrm{DM}\right), c$ is the GP rate constant $\left(\mathrm{h}^{-1}\right), t$ incubation time $(\mathrm{h})$.

The ME ( $\mathrm{MJ} \mathrm{kg}^{-1} \mathrm{DM}$ ) was calculated using equation of Menke et al. (1979) as follows: ME (MJ kg-1 $\mathrm{DM})=2.20+0.136 \mathrm{GP}+0.057 \mathrm{CP} \quad\left(R^{2}=0.94\right)$ where, GP is $24 \mathrm{~h}$ net GP (ml $\left.200 \mathrm{mg}^{-1} \mathrm{DM}\right), \mathrm{CP}$ is crude protein $(\%)$. The in vitro organic matter digestibility (OMD) of foliage was calculated using equation of Menke et al. (1979) as follows: in vitro OMD $(\%)=14.88+0.889 \mathrm{GP}+0.45 \mathrm{CP}+0.0651 \mathrm{XA}$ where, GP is $24 \mathrm{~h}$ net gas production $\left(\mathrm{ml} 200 \mathrm{mg}^{-1}\right.$ $\mathrm{DM}), \mathrm{CP}$ is crude protein (\%) and XA is ash content (\%).

The DMD was determined at the end of the incubation period as previously described in Vallejo et al. (2016). Briefly, after $96 \mathrm{~h}$ of incubation, the contents of each syringe were filtered through sintered glass crucibles under vacuum and the fermentation residues were dried at $105{ }^{\circ} \mathrm{C}$ overnight. Weight loss after drying was taken as undegradable DM. The DMD $\left(\mathrm{mg} \mathrm{g}^{-1} \mathrm{DM}\right)$ at $96 \mathrm{~h}$ of incubation was calculated as the difference between substrate DM content and its undegradable DM.
Statistical analysis

The chemical composition, in vitro GP kinetics, in vitro OMD, DMD and ME contents data was analysed as completely randomized design with a $2 \times 2$ factorial treatment arrangement (i.e., 2 foliage types (hulls and leaves) with 2 harvest types (fresh green and dry), using the GLM of SAS (2002). Before analysis, the data of three runs within the same sample were averaged. The statistical model was:

$\mathrm{Y}_{\mathrm{ijk}}=\mu+\mathrm{S}_{\mathrm{i}}+\mathrm{R}_{\mathrm{j}}+\mathrm{S}_{\mathrm{i}} \times \mathrm{R}_{\mathrm{j}}+\varepsilon_{\mathrm{ijk}}$

where $Y_{i j k}$ represents the general observation of chemical composition, in vitro GP kinetics, in vitro OMD, DMD and ME contents, $S_{i}$ the $i$ th effect of foliage type on the observed parameters; $\mathrm{R}_{\mathrm{j}}$ is the $j$ th effect of harvest types on the observed parameters. The $S_{i} \times R_{j}$ term presents $i$ th and $j$ th interaction effects of foliage and harvest types on chemical composition, in vitro GP kinetics, in vitro OMD, DMD and $\mathrm{ME}$ contents, and $\varepsilon_{\mathrm{ijk}}$ the standard error term common for all observations. Mean differences were declared significant at $P<0.05$. The means were separated using the Tukey's Multiple Range Test (Pearse and Hartley 1966).

\section{Results}

There were considerable variations $(P<0.05)$ between almond hulls and leaves in terms of chemical compositions. The GAL contained $81 \mathrm{~g} \mathrm{CP} \mathrm{kg}^{-1} \mathrm{DM}$ while DAH contained $103 \mathrm{~g} \mathrm{CP} \mathrm{kg}^{-1} \mathrm{DM}$. The $\mathrm{CP}$ was higher $(P=0.0003)$ in dry (leaves and hulls) than in green (leaves and hulls) samples. The ash content ranged from 99.2 to $181.5 \mathrm{~g} \mathrm{~kg}^{-1} \mathrm{DM}$ in DAH and DAL, respectively, $(P=0.0041)$. Leaves had higher $(P=0.0001)$ ash content than hulls. The EE content of the leaves was higher $(P=0.0001)$ than hulls. Moreover, the dry almond had higher $(P=0.0036)$ EE content than the fresh green. The EE content ranged from 27 for DAH to $65 \mathrm{~g} \mathrm{~kg}^{-1}$ for DAL $(P=0.0018)$. The ADF and NDF content ranged from 185 to 304 and 444 to $620 \mathrm{~g} \mathrm{~kg}^{-1} \mathrm{DM}$ $(P=0.04)$, for GAL and DAH, respectively. The hulls showed higher $(P=0.0001)$ content of both ADF and NDF than the leaves. The WSC content was highest $(P=0.0001)$ in almond leaves (Table 1$)$. 
Table 1 Chemical composition ( $\mathrm{g} \mathrm{kg}^{-1} \mathrm{DM}$ ) of almond tree (Prunus dulcis D. A. Webb syn. Prunus amygdalus; var. Shokoufeh) leaves versus hulls, and green versus dry leaves as feed for ruminants $(n=10$ samples $)$

\begin{tabular}{llccccccccccc}
\hline & GAL & DAL & GAH & DAH & SEM & $P$ value & Hulls & Leaves & $P$ value & Dry & Fresh green & $P$ value \\
\hline DM & $970.5^{\mathrm{b}}$ & $980.3^{\mathrm{a}}$ & $967.5^{\mathrm{b}}$ & $971.2^{\mathrm{b}}$ & 12.81 & 0.0339 & $969.4^{\mathrm{b}}$ & $975.4^{\mathrm{a}}$ & 0.0062 & $975.8^{\mathrm{a}}$ & $969.0^{\mathrm{b}}$ & 0.0032 \\
$\mathrm{OM}$ & $847.9^{\mathrm{b}}$ & $818.5^{\mathrm{c}}$ & $885.2^{\mathrm{a}}$ & $900.8^{\mathrm{a}}$ & 9.82 & 0.0041 & $893.0^{\mathrm{a}}$ & $833.2^{\mathrm{b}}$ & 0.0001 & 859.7 & 866.6 & 0.2586 \\
$\mathrm{Ash}$ & $152.1^{\mathrm{b}}$ & $181.5^{\mathrm{a}}$ & $114.8^{\mathrm{c}}$ & $99.2^{\mathrm{c}}$ & 2.98 & 0.0041 & $106.9^{\mathrm{b}}$ & $166.7^{\mathrm{a}}$ & 0.0001 & 140.2 & 133.3 & 0.2586 \\
$\mathrm{CP}$ & $81.3^{\mathrm{b}}$ & $103.1^{\mathrm{a}}$ & $81.1^{\mathrm{b}}$ & $103.4^{\mathrm{a}}$ & 3.62 & 0.4480 & 92.3 & $92.2^{\mathrm{a}}$ & 0.9863 & $103.3^{\mathrm{a}}$ & $81.2^{\mathrm{b}}$ & 0.0003 \\
$\mathrm{EE}$ & $52.1^{\mathrm{b}}$ & $64.7^{\mathrm{a}}$ & $29.6^{\mathrm{c}}$ & $26.7^{\mathrm{c}}$ & 1.27 & 0.0018 & $26.3^{\mathrm{b}}$ & $58.1^{\mathrm{a}}$ & 0.0001 & $45.3^{\mathrm{a}}$ & $39.0^{\mathrm{b}}$ & 0.0036 \\
$\mathrm{ADF}$ & $185.0^{\mathrm{b}}$ & $200.1^{\mathrm{b}}$ & $296.6^{\mathrm{a}}$ & $303.5^{\mathrm{a}}$ & 1.2 & 0.0566 & $300.0^{\mathrm{a}}$ & $192.5^{\mathrm{b}}$ & 0.0001 & 251.8 & 240.8 & 0.1512 \\
$\mathrm{NDF}$ & $444.0^{\mathrm{d}}$ & $473.3^{\mathrm{c}}$ & $598.3^{\mathrm{b}}$ & $619.8^{\mathrm{a}}$ & 10.75 & 0.0400 & $609.0^{\mathrm{a}}$ & $458.6^{\mathrm{b}}$ & 0.0001 & $546.5^{\mathrm{a}}$ & $521.2^{\mathrm{b}}$ & 0.0004 \\
WSC & $186.9^{\mathrm{a}}$ & $188.4^{\mathrm{a}}$ & $126.3^{\mathrm{c}}$ & $141.3^{\mathrm{b}}$ & 4.35 & 0.0100 & $132.8^{\mathrm{b}}$ & $187.6^{\mathrm{a}}$ & 0.0001 & $164.8^{\mathrm{a}}$ & $156.6^{\mathrm{b}}$ & 0.0036 \\
\hline
\end{tabular}

$D M$ dry matter, $O M$ organic matter, $C P$ crude protein, $E E$ ether extract, $A D F$ acid detergent fibre, $N D F$ neutral detergent fibre, $W S C$ water soluble carbohydrates, $G A L$ green almond leaf, $D A L$ dry almond leaf, $G A H$ green almond hulls, $D A H$ dry almond hulls

Means within same row with different superscript letters are significantly different $(P<0.05)$

The highest GP was observed for DAH compared to the other treatments (Fig. 1). The DAH had the highest $(P=0.0001) \mathrm{GP}_{24}$ and $\mathrm{GP}_{96}$. The DAH had the highest $(P=0.0001)$ potential GP (i.e., $b)$, while the values GP rate (i.e., $c$ ) was highest for GAL and GAH $(P=0.034)$, ME was highest for DAH $(P=0.0001)$, and in vitro OMD was highest for DAH $(P=0.0001)$. The highest DMD $(P=0.0001)$ values were obtained with DAH followed by GAL, DAL and GAH, respectively (Table 2 ).

\section{Discussion}

\section{Chemical composition}

In the current study, dry almond sample (leaves and hulls) had higher DM, CP, EE and NDF contents than the fresh green sample (leaves and hulls). Additionally, hulls had higher OM, ADF and NDF contents than leaves. The chemical composition and nutritive value of plants and plant parts is affected

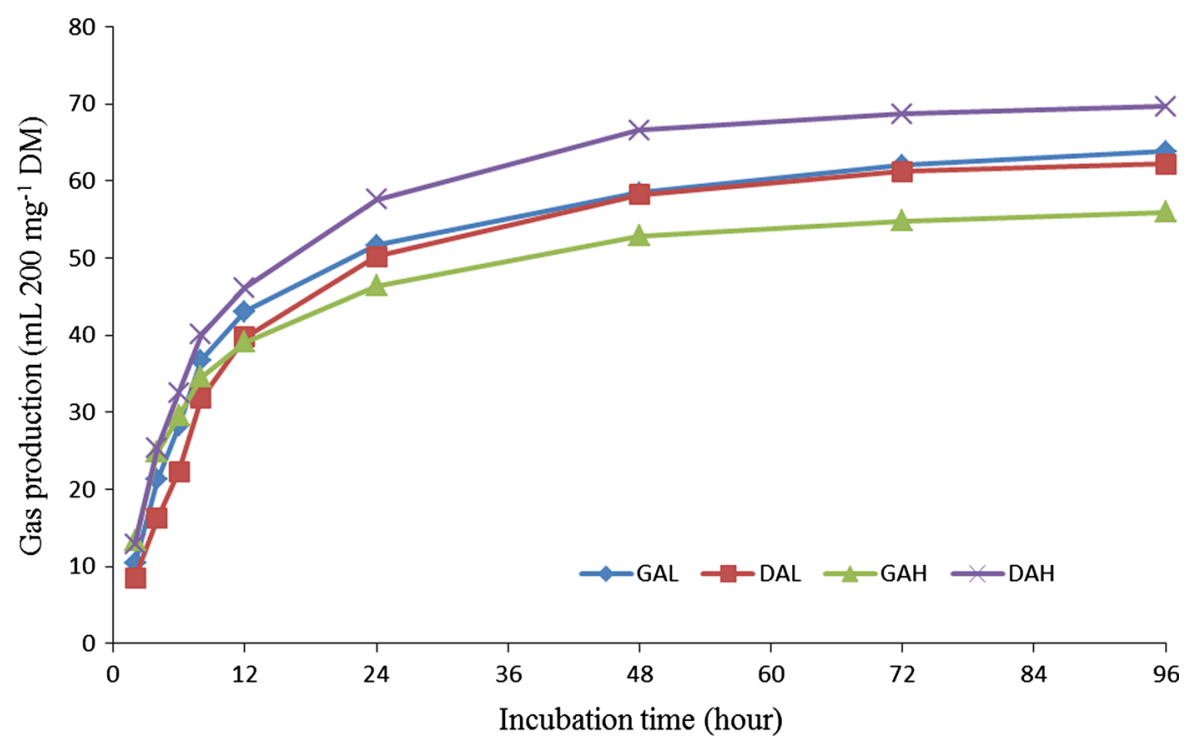

Fig. 1 In vitro gas production profile of almond tree (Prunus dulcis D. A. Webb syn. Prunus amygdalus; var. Shokoufeh) leaves versus hulls, and green versus dry leaves as feed for ruminants (mL gas $\left.200 \mathrm{mg}^{-1} \mathrm{DM}\right) . G A L$ green almond leaf, $D A L$ dry almond leaf, $G A H$ green almond hulls, $D A H$ dry almond hulls 
Table 2 Gas production after 24 and $96 \mathrm{~h}$, kinetics and digestibility of almond tree (Prunus dulcis D. A. Webb syn. Prunus amygdalus; var. Shokoufeh) leaves versus hulls, and green versus dry leaves as feed for ruminants $(\mathrm{n}=10$ samples)

GAL DAL GAH DAH $\quad$ SEM $P$ value Leaves Hulls $P$ value Dry $\begin{gathered}\text { Fresh } \\ \text { green }\end{gathered} \quad P$ value

\begin{tabular}{lccccccccccccc}
$\begin{array}{c}\text { Gas production } \\
\text { and kinetics }\end{array}$ & \multicolumn{10}{c}{$10.0^{2}$} \\
$\mathrm{GP}_{24}$ & $51.7^{\mathrm{b}}$ & $50.2^{\mathrm{b}}$ & $46.6^{\mathrm{c}}$ & $57.6^{\mathrm{a}}$ & 0.80 & 0.0001 & $50.9^{\mathrm{a}}$ & $52.0^{\mathrm{a}}$ & 0.0523 & $49.04^{\mathrm{b}}$ & $53.90^{\mathrm{a}}$ & 0.0001 \\
$\mathrm{GP}_{96}$ & $63.8^{\mathrm{b}}$ & $62.2^{\mathrm{b}}$ & $56.0^{\mathrm{c}}$ & $69.67^{\mathrm{a}}$ & 1.08 & 0.0001 & $63.0^{\mathrm{a}}$ & $62.8^{\mathrm{a}}$ & 0.7427 & $59.90^{\mathrm{b}}$ & $65.95^{\mathrm{a}}$ & 0.0001 \\
$b$ & $60.06^{\mathrm{b}}$ & $60.72^{\mathrm{b}}$ & $46.5^{\mathrm{c}}$ & $63.4^{\mathrm{a}}$ & 1.10 & 0.0001 & $60.4^{\mathrm{a}}$ & $54.9^{\mathrm{b}}$ & 0.0001 & $53.28^{\mathrm{b}}$ & $62.04^{\mathrm{a}}$ & 0.0001 \\
$c$ & $0.100^{\mathrm{a}}$ & $0.084^{\mathrm{c}}$ & $0.099^{\mathrm{a}}$ & $0.091^{\mathrm{b}} 0.0021$ & 0.0340 & $0.092^{\mathrm{a}}$ & $0.095^{\mathrm{a}}$ & 0.1323 & $0.099^{\mathrm{a}}$ & $0.088^{\mathrm{b}}$ & 0.0001 \\
$\mathrm{In}$ vitro OMD & $621.9^{\mathrm{b}}$ & $611.7^{\mathrm{c}}$ & $573.1^{\mathrm{d}}$ & $672.1^{\mathrm{a}}$ & 1.40 & 0.0001 & $616.8^{\mathrm{b}}$ & $622.6^{\mathrm{a}}$ & 0.0001 & $597.5^{\mathrm{b}}$ & $641.9^{\mathrm{a}}$ & 0.0001 \\
$\mathrm{In}$ vitro DMD & $527.3^{\mathrm{b}}$ & $500.5^{\mathrm{d}}$ & $507.3^{\mathrm{c}}$ & $605.0^{\mathrm{a}}$ & 1.30 & 0.0001 & $513.9^{\mathrm{b}}$ & $556.1^{\mathrm{a}}$ & 0.0001 & $517.3^{\mathrm{b}}$ & $552.7^{\mathrm{a}}$ & 0.0001 \\
$\mathrm{ME}$ & $9.26^{\mathrm{b}}$ & $9.07^{\mathrm{b}}$ & $8.54^{\mathrm{c}}$ & $10.07^{\mathrm{a}}$ & 0.112 & 0.0001 & $9.16^{\mathrm{a}}$ & $9.30^{\mathrm{a}}$ & 0.0691 & $8.90^{\mathrm{b}}$ & $9.57^{\mathrm{a}}$ & 0.0001 \\
\hline
\end{tabular}

$\mathrm{GP}_{24}-\mathrm{GP}_{96}$ : gas production ( $\mathrm{mL} 200 \mathrm{mg}^{-1} \mathrm{DM}$ ) after incubation time of 24 and $96 \mathrm{~h}$; b: potential gas production (mL $200 \mathrm{mg}^{-1}$ $\mathrm{DM})$; c: gas production rate constant $\left(\mathrm{h}^{-1}\right)$; ME: metabolisable energy (MJ kg $\left.{ }^{-1} \mathrm{DM}\right)$; in vitro DMD: in vitro dry matter digestibility ( $\left.\mathrm{mg} \mathrm{g}^{-1} \mathrm{DM}\right)$; in vitro OMD: In vitro organic matter digestibility ( $\left.\mathrm{mg} \mathrm{g}^{-1} \mathrm{DM}\right)$

Means within same row with different superscript letters are significantly different $(P<0.05)$

$G A L$ green almond leaf, $D A L$ dry almond leaf, $G A H$ green almond hulls, $D A H$ dry almond hulls

by many factors including genotype, growing conditions, stage of growth, environment, and the interaction between genotype and environment (Arhab et al. 2009; Elghandour et al. 2014). Environmental conditions include the soil, agronomic practice, climatic conditions, harvesting and post harvesting treatments (Arhab et al. 2009; Elghandour et al. 2014).

Bagheripour et al. (2008) reported that sun drying of pistachio by-product samples increased its $\mathrm{CP}$, $\mathrm{NDF}, \mathrm{ADF}$ and lignin contents. These changes are due to losses of water and hexoses as plant cells respire resulted in concentration of other constituents (Salem et al. 2012). Besides, Van Soest (1994) observed increased NDF, lignin and N contents with sun drying through the disproportionate loss of carbon dioxide, which is in agreement with the results of the current study. However, sun drying of foliages per se does not usually result in changes in its nutrient contents. Salem et al. (2012) reported that sun drying of Atriplex halimus foliage did not affect its OM, CP, EE and dietary fibre contents. It should be noted that the dry almond leaves (DAL) were collected from under the trees i.e., these where dry mature leaves which had fallen off after leaf senescence.

In ruminant animals, the extent to which foliages are utilized depends on its chemical composition (Ahmed et al. 2015a, b; Kholif et al. 2015, 2016). The $\mathrm{CP}$ content of almond tree hulls reported in the current study (i.e., $92.3 \mathrm{~g} \mathrm{~kg}^{-1} \mathrm{DM}$ ) was higher than previously reported (Getachew et al. 2004; Yalchi and Kargar 2010). The CP content of almond tree hulls has been reported to range from 48.7 (Reed and Brown 1988) to $80.0 \mathrm{~g} \mathrm{~kg}^{-1} \mathrm{DM}$ (Getachew et al. 2004). Yalchi (2010) reported the CP content of almond tree hulls was $28.6 \mathrm{~g} \mathrm{~kg}^{-1} \mathrm{DM}$ where as Jafari et al. (2011) observed that the $\mathrm{CP}$ content of three Iranian almond varieties ranged from 23.2 to $32.7 \mathrm{~g} \mathrm{~kg}^{-1} \mathrm{DM}$. Elsewhere, Homedes (1985) reported that the American almond tree hulls contain 54.0 to $64.0 \mathrm{~g} \mathrm{CP} \mathrm{kg}^{-1}$ DM. These results are lower than those of the current study. Since the foliage (hulls and leaves) contains over $80.0 \mathrm{~g} \mathrm{CP} \mathrm{kg}^{-1}$, it can be consider as intermediate quality roughages. This range of $\mathrm{CP}$ is sufficient to produce ammonia required for the growth and activity of ruminal microorganisms (Kamalak et al. 2005).

In the current study, the ash content of the almond hulls was $107.0 \mathrm{~g} \mathrm{~kg}^{-1} \mathrm{DM}$ which is higher than the level reported by Homedes (1985) for the American almond hulls. The NDF and ADF levels ranged from 444.0 to $620.0 \mathrm{~g} \mathrm{~kg}^{-1} \mathrm{DM}$ and from 185.0 to $304.0 \mathrm{~g} \mathrm{~kg}^{-1} \mathrm{DM}$, respectively. The range of NDF and ADF reported by Homedes (1985) were 210.0 to $290.0 \mathrm{~g} \mathrm{~kg}^{-1} \mathrm{DM}$ for NDF and 244.0 to $296.0 \mathrm{~g} \mathrm{~kg}^{-1}$ DM for ADF. Norollahi et al. (2005) reported NDF and ADF contents of 211 and $117 \mathrm{~g} \mathrm{~kg}^{-1} \mathrm{DM}$, respectively, for almond hulls from the central region 
of Iran. Jafari et al. (2015) observed that almond hulls contain NDF and ADF contents of 300 and $220 \mathrm{~g} \mathrm{~kg}^{-1}$ $\mathrm{DM}$, respectively. These results compared to those of the current study, indicates a wide difference in NDF and ADF contents even from among Iranian almond hulls only. The ADF content is a good index of feed nutritive value and has a high correlation with digestible energy in almond hulls (Aguilar et al. 1984).

Getachew et al. (2004) observed that WSC content of almond hulls was higher than that of alfalfa and was comparable to that of sugar beet pulp. The WSC content of the dry almond was higher than that for the fresh green almond. These changes are due to losses of water as plant cells respire resulted in concentration of other constituents (Salem et al. 2012) resulting in lower in vitro OMD and DMD for the dry foliage. This is in contrast to Salem et al. (2012) who found that sun drying A. halimus reduced its WSC content compared to fresh foliage. From the current chemical composition results and others in vivo experiments in sheep (Norollahi et al. 2005), dairy cow (Aguilar et al. 1984), and goat (Reed and Brown 1988), almond shows a good nutritive value equivalent to $65-90 \%$ energy value of barley.

\section{Gas production}

Ruminal fermentation of structural and non-structural carbohydrates produces gases, acetate, propionate and butyrate (Makkar et al. 1995; Salem et al. 2014; Rodriguez et al. 2015). The rate and extent GP can be considered a good indicator of the digestibility and fermentability of feeds and microbial protein synthesis (Elahi et al. 2014; Elghandour et al. 2015a, b). The different kinetics of GP depends on the chemical composition of the fermented substrates that illuminates their nutritional value as feeds (Elghandour et al. 2015a, b). In the current study, potential GP (i.e., $b$ fraction) was correlated to CP contents of incubated substrates; however, fermentability of protein produces relatively little gas compared to carbohydrate fermentation (Makkar et al. 1995). The DAH substrate produced the highest $b$ value compared to other substrates, which reveals the effect of CP content on GP compared to the WSC contents, which was low in the DAH substrate. The foliage type and harvesting time are two other factors that significantly affect in vitro GP and fermentation kinetics. The higher GP during the first $24 \mathrm{~h}$ of incubation with DAH suggests that greater fermentation occurred during the first $24 \mathrm{~h}$ of incubation compared with the other treatments. The tendency $(P=0.0523)$ for differences in GP (at $24 \mathrm{~h}$ of fermentation) among hulls and leaves could be due to difference in NDF and ADF fractions (Rubanza et al. 2005). The results of the current study were higher than those of Jafari et al. (2011) who reported that GP of four varieties of almond hulls varied between 64.0 and $81.0 \mathrm{~mL} \mathrm{~g}^{-1} \mathrm{DM}$.

Foliage of DAH had the highest GP during the incubation period. However, potential GP ( $b$ fraction) of almond hulls was lower than almond leaves. The DAH had the highest ME, in vitro OMD, and DMD. These differences could be due to variations in CP and NDF contents of the foliage. The higher in vitro OMD, DMD, $\mathrm{ME}$ and $b$ fraction for DAH indicate its higher fermentability and digestion. It is speculated that when hulls and leaves were sun-dried, this could have lowered the concentration of phenolic compounds in them thus improving their nutritive value. However antinutritional factors were not measured in the current study. Salem et al. (2012) reported that sun-drying reduced the concentration of condensed tannins, total phenolics, saponins, alkaloids, and aqueous fraction by 52.0, 63.0, 30.0 and $73.0 \%$, respectively relative to the fresh $A$. halimus foliage resulting in a lower inhibitory effect on ruminal bacteria when animals were fed such feeds.

Fresh almond green and hulls have fairly high energy value for ruminant animals and have comparable energy value to barley (Aguilar et al. 1984). The National Research Council (NRC 1981) nutrient requirement tables for goats show that a goat with an average body weight of $30 \mathrm{~kg}$ and producing $1 \mathrm{~kg}$ of milk with $35 \mathrm{~g}_{\text {fat }} \mathrm{kg}^{-1}$ requires 5.43 MJ of ME as a maintenance requirements plus 5.06 MJ of ME for the production of $1 \mathrm{~kg}$ milk ( $35 \mathrm{~g}_{\text {fat }} \mathrm{kg}^{-1}$ ) totalling 10.5 MJ as a total ME requirements. In the present study, the ME energy concentrations ranged between 8.54 and 10.07 for $\mathrm{GAH}$ and $\mathrm{DAH}$, respectively suggesting that almond can be fed alone to cover the maintenance requirements of goats. However, for milk or meat production, feed supplementation with concentrates would be required.

\section{Conclusions}

The results of the current study suggest that almond hulls and leaves have a good nutritional potential to 
cover the maintenance nutrient requirements of small ruminants especially during periods of feed scarcity or during dry-seasons. Moreover, almond hulls and leaves can be used as supplement to low quality mature pasture and crop residues. However, more studies are warranted to better characterize these feeds in in vivo animal feeding trials.

\section{References}

Aguilar AA, Smith NE, Baldwin RL (1984) Nutritional value of almond hulls for dairy cows. J Dairy Sci 67:97-103

Ahmed MH, Elghandour MMY, Salem AZM, Zeweil HS, Kholif AE, Klieve AV, Abdelrassol AMA (2015a) Influence of Trichoderma reesei or Saccharomyces cerevisiae on performance, ruminal fermentation, carcass characteristics and blood biochemistry of lambs fed Atriplex nummularia and Acacia saligna mixture. Livest Sci 180:90-97

Ahmed MH, Salem AZM, Zeweil HS, Sun XZ, Kholif AE, Elghandour MMY, Bahar MSI (2015b) Growth performance and carcass characteristics of lambs fed halophytes as a partial or whole replacement of berseem hay. Small Rumin Res 128:1-9

Alibes X, Maestre MR, Munoz F, Combellas J, Rodriguez J (1983) Nutritive value of almond hulls for sheep. Anim Feed Sci Technol 8:63-67

AOAC (1997) Official method of analysis, 16th edn. Association of Analytical Chemists, Arlington

Arhab R, Macheboeuf D, Aggoun M, Bousseboua H, Viala D, Besle JM (2009) Effect of polyethylene glycol on in vitro gas production and digestibility of tannin containing feedstuffs from north African arid zone. Trop Subtrop Agroecosyst 10:475-486

Bagheripour E, Rouzbehan Y, Alipour D (2008) Effects of ensiling, air-drying and addition of polyethylene glycol on in vitro gas production of pistachio by-products. Anim Feed Sci Technol 146:327-336

Cedillo J, Vázquez-Armijo JF, González-Reyna A, Salem AZM, Kholif AE, Hernández-Meléndez J, Martínez-González JC, de Oca Jiménez RM, Rivero N, López D (2014) Effects of different doses of Salix babylonica extract on growth performance and diet in vitro gas production in Pelibuey growing lambs. Ital J Anim Sci 13:609-613

Chen P, Cheng Y, Deng S, Lin X, Huang G, Ruan R (2010) Utilization of almond residues. Int J Agric Biol 3(4):1-18

Elahi MY, Nia MM, Salem AZM, Mansouri H, Olivares-Pérez J, Kholif AE (2014) Effect of polyethylene glycol on in vitro gas production kinetics of Prosopis cineraria leaves at different growth stages. Ital J Anim Sci 13:363-368

Elghandour MMY, Vázquez-Chagoyán JC, Salem AZM, Kholif AE, Martínez Castañeda JS, Camacho LM, Cerrillo-Soto MA (2014) Effects of Saccharomyces cerevisiae at direct addition or pre-incubation on in vitro gas production kinetics and degradability of four fibrous feeds. Ital J Anim Sci 13:295-301
Elghandour MMY, Kholif AE, Bastida AZ, Martinez DLP, Salem AZM (2015a) In vitro gas production of five diets of different concentrate and maize silage ratios influenced by increasing levels of chemically characterized extract of Salix babylonica. Turk J Vet Anim Sci 39:186-194

Elghandour MMY, Kholif AE, Marquez-Molina O, VazquezArmijo JF, Puniya AK, Salem AZM (2015b) Influence of individual or mixed cellulase and xylanase mixture on in vitro rumen gas production kinetics of total mixed rations with different maize silage and concentrate ratios. Turk J Vet Anim Sci 39(4):435-442

Fadel JG (1999) Quantitative analyses of selected plant byproduct feedstuffs, a global perspective. Anim Feed Sci Technol 79:225-268

FAO (2007) http://faostat.fao.org/site/567/DesktopDefault. aspx?PageID=567\#ancor

Getachew G, Robinson PH, DePeters EJ, Taylor SJ (2004) Relationship between chemical composition, dry matter degradation and in vitro gas production of several ruminant feeds. Anim Feed Sci Technol 111:57-71

Homedes MJ (1985) Almond hulls in swine diet reduce body fat. Calif Agric 47(3):27-28

Jafari S, Alizadeh AR, Imani A (2011) Nutritive value of different varieties of almond (Prunus dulcis) hulls. Res Opin Anim Vet Sci 1(11):734-738

Jafari S, Alizadeh A, Imni A, Meng GY, Rajion MA, Ebrahimi M (2015) In situ degradation of almond (Prunus dulcis L.) hulls, a potential feed material for ruminants. Turk J Vet Anim Sci 39(6):676-681

Kamalak A, Canbolat O, Gurbuz Y, Ozay O, Ozkose E (2005) Chemical composition and its relationship to in vitro gas production of several tannin containing trees and shrub leaves. Asian-Australas J Anim Sci 18:203-208

Kholif AE, Gouda GA, Morsy TA, Salem AZM, Lopez S, Kholif AM (2015) Moringa oleifera leaf meal as a protein source in lactating goat's diets: feed intake, digestibility, ruminal fermentation, milk yield and composition, and its fatty acids profile. Small Rumin Res 129:129-137

Kholif AE, Morsy TA, Gouda GA, Anele UY, Galyean ML (2016) Effect of feeding diets with processed Moringa oleifera meal as protein source in lactating Anglo-Nubian goats. Anim Feed Sci Technol. doi:10.1016/j.anifeedsci. 2016.04.012

Makkar HPS, Blummel M, Becker K (1995) Formation of complexes between polyvinyl pyrrolidones or polyethylene glycols and tannins and their implications in gas production and true digestibility in in vitro techniques. $\mathrm{Br} \mathrm{J}$ Nut 73:897-933

Menke KH, Steingass H (1988) Estimation of the energetic feed value obtained from chemical analysis and gas production using rumen fluid. Anim Res Dev 28:7-55

Menke KH, Raab L, Salewski A, Steingass H, Fritz D, Schneider W (1979) The neutral detergent fibre, and nonstarch polysaccharides in relation to animal nutrition. J Dairy Sci 74:3583-3597

Ministry of Agriculture, Fisheries and Food (MAFF) (1982) The analysis of agricultural materials, 2nd edn. MAFF, London

Norollahi H, Kamalzadeh A, Karimi A (2005) Determination of chemical composition and digestibility of almond hull. Acta Hortic 726:591-594 
NRC (1981) National research council, nutrient requirements of goats, committee on animal nutrition. National Academy Press, Washington

NRC (1985) Nutrient requirements of sheep, 6th revised editions. National Academy Press, Washington

Ørskov ER, McDonald I (1979) The estimation of protein degradability in the rumen from incubation measurements weighted according to rate of passage. J Agric Sci 92:499-503

Pearse ES, Hartley HO (1966) Biometrika tables for statisticians, vol 1. Cambridge University Press, Cambridge

Pinto F, Vonghia G, Ciruzzi B, Montemurro O, Marsico G (1989) In vivo digestibility and nutritive value of undecorticateds of-flower oilseed meal, hydraulic extracted, of two mixtures made up of almond hulls, olive twigs and sofflower oilseed meal. In: Second international sofflower conference. Hyderabad, India

Reed BA, Brown DL (1988) Almond hulls in diets for lactating goats: Effects on yield and composition of milk, feed intake and digestibility. J Dairy Sci 71:530-533

Rodriguez MP, Mariezcurrena MD, Mariezcurrena MA, Lagunas BC, Elghandour MMY, Kholif AM, Kholif AE, Almaráz EM, Salem AZM (2015) Influence of live cells or cells extract of Saccharomyces cerevisiae on in vitro gas production of a total mixed ration. Ital $\mathrm{J}$ Anim Sci 14(4):590-595

Rubanza CDK, Shem MN, Otsyina R, Bakengesa SS, Ichinohe T, Fujihara T (2005) Polyphenolics and tannins effect on in vitro digestibility of selected Acacia species leaves. Anim Feed Sci Technol 119:129-142

Salem AZM, Hassan AA, Khalil MS, Gado HM, Alsersy H, Simbaya J (2012) Effects of sun-drying and exogenous enzymes on nutrients intake, digestibility and nitrogen utilization in sheep fed Atriplex halimus foliages. Anim Feed Sci Technol 171:128-135
Salem AZM, Ryena AG, Elghandour MMY, Camacho LM, Kholif AE, Salazar MC, Domínguez IA, Jiménez RM, Almaraz EM, Martínez AGL, Mariezcurrena MA (2014) Influence of Salix babylonica extract in combination or not with increasing levels of minerals mixture on in vitro rumen gas production kinetics of a total mixed ration. Ital $\mathbf{J}$ Anim Sci 13:873-879

SAS Institute (2002) SAS user's Guide Int., version 9.1. Statistical Analysis Institute, Cary

Sfahlan AJ, Mahmoodzadeh A, Hasanzadeh A, Heidari R, Jamei $\mathrm{R}$ (2009) Antioxidant and antiradicals in almond hull and shell (Amygdalus communis L.) as a function of genotype. Food Chem 115:529-533

Vallejo LH, Salem AZM, Kholif AE, Elghangour MMY, Fajardo RC, Rivero N, Bastida AZ, Mariezcurrena MD (2016) Influence of cellulase or xylanase on the in vitro rumen gas production and fermentation of corn stover. Indian J Anim Sci 86(1):70-74

Van Soest PJ (Ed) (1994) Forage preservation. In: Nutrition ecology of the ruminant, 2nd edn. Cornell University Press, Ithaca, pp 213-217

Van Soest PJ, Robertson JB, Lewis BA (1991) Methods of dietary fibre, neutral detergent fibre and non-starch polysaccharides in relation to animal nutrition. J Dairy Sci 74:3583-3597

Wijerante SSK, Abou-Zaid MM, Shahidi F (2006) Antioxidant polyphenols in almond and its co products. J Agric Food Chem 54:312-318

Yalchi T (2010) Effects of urea and aqueous ammonia treatment on the nutritive value of triticale straw. J Food Agric Environ 8(1):69-72

Yalchi T, Kargar S (2010) Chemical composition and in situ ruminal degradability of dry matter and neutral detergent fibre from almond hulls. J Food Agric Environ 8(2):781-784 